\title{
APPLICATION OF MCDM APPROACH TO EVALUATE THE CRITICAL SUCCESS FACTORS OF TOTAL QUALITY MANAGEMENT IN THE HOSPITALITY INDUSTRY
}

\author{
Ahmad JUSOH${ }^{1}$, Abbas MARDANI ${ }^{1}$, Rozeyta OMAR ${ }^{2}$, \\ Dalia ŠTREIMIKIENE ${ }^{3}$, Zainab KHALIFAH ${ }^{1}$, Ali SHARIFARA ${ }^{4}$ \\ ${ }^{1}$ Azman Hashim International Business School, \\ Universiti Teknologi Malaysia (UTM), Skudai Johor 81310, Malaysia \\ ${ }^{2}$ School of Education, Faculty of Social Sciences and Humanities, \\ Universiti Teknologi Malaysia (UTM), Skudai Johor 81310, Malaysia \\ ${ }^{3}$ Lithuanian Institute of Agrarian Economics, V. Kudirkos g. 18-2, 03105 Vilnius \\ ${ }^{4}$ Department of Computer Science and Engineering, University of Texas at Arlington, \\ Arlington, Texas, United States, 76019-0015
}

Received 03 Octobre 2017; accepted 27 April 2018

\begin{abstract}
Although many studies have focused on significant role of total quality management (TQM) in literature, little attention has been paid to using the fuzzy multiple criteria decision making (FMCDM) for analysis TQM factors especially in the context of hospitality. The purpose of this study is to identify, prioritize and evaluate the TQM critical success factors (CSFs) in hospitality industry by integrating the theory of fuzzy sets, quantitative and qualitative approaches. Primary criteria to evaluate TQM CSFs are achieved by the literature survey, and the Fuzzy Delphi Method (FDM) has been used by experts for evaluating of soft and hard TQM CSFs. In the following step, we employed the Fuzzy Analytic Hierarchy Process (FAHP) to find the weights of criteria. The results of this study indicated that, internal and external cooperation had the first rank among other CSFs in hospitality industry. In addition, the second and third rank in soft aspect includes customer focus and leadership respectively. The findings of this study shown guidance to practitioners and managers of quality to implement of TQM in their organizations, effectively by using the suggested set of identified TQM CSFs.
\end{abstract}

Keywords: critical success factors, fuzzy analytic hierarchy process, fuzzy Delphi method, hospitality industry, total quality management, quality management.

JEL Classification: M11, L83, C44, D7.

\section{Introduction}

In the past 50 years, total quality management (TQM) has been broadly adopted by many firms Andrade, Mendes and Lourenço (2017); Aoun and Hasnan (2017); Chuang, Chen and

\footnotetext{
*Corresponding author. E-mail: mabbas3@live.utm.my
} 
Tsai (2015); Fernandes, Sampaio, Sameiro and Truong (2017); Fu, Chou, Chen and Wang (2015). Andrade et al. (2017) analyzed the differences in the perception of empowerment between TQM-based firms and non-TQM-based firms. The findings of this paper found that there were the significant statistical differences in factors of empowerment among the two groups of companies. Aoun and Hasnan (2017) examined the impact of soft TQM on employees innovation skills in 13 Lebanese hospitals. The results of this study found that, soft TQM factors influenced on the employees' innovation skills. In addition; the findings indicated that people-based management influenced on employees' innovation skills and there was not the relationship between employees' innovation skills and continuous improvement in Lebanese hospitals. Chuang et al. (2015) examined the influence motivations on middle management employees' knowledge-sharing intentions in the implementation of TQM in 395 middle management employees in 50 Taiwanese ISO 9001:2000-certified firms. The findings of this paper found that there were the significant relationships between self-efficacy, subjective norms, perceived ethics and attitudes towards knowledge sharing in the implementations of TQM. Fernandes et al. (2017) developed the theoretical foundation for integration of supply chain management (SCM) and TQM in the balanced scorecard perspectives. The results of this paper found that the integration of SCM and TQM can enhance organizational benefits significantly. Fu et al. (2015) investigated the role of TQM organizational culture (OC) in seven Taiwanese companies for attain the high level of business excellence. The results of this paper demonstrated that the business performance in companies had the positive relationship with TQM OC.

According to current body of literature, TQM has been implemented in both service and manufacturing firms; however, there are few of studies focused on the service firms specifically in the context of hospitality industry (Bouranta, Psomas, \& Pantouvakis, 2017; Drosos, Skordoulis, Chalikias, Kalantonis, \& Papagrigoriou, 2017; Tarí, Pereira-Moliner, Pertusa-Ortega, López-Gamero, \& Molina-Azorín, 2017). According to the current literature and theories regarding to TQM, we found there are some differences in the implementation of TQM practices in service and manufacturing industries. A number of research studies have investigated the differences in the implementation of TQM between service industry and manufacturing industry. Beaumont, Sohal and Terziovski (1997) examined the differences of TQM in 85 service companies and 261 manufacturing companies, the results of this study demonstrated that, a little attention has been paid about using the QM tools, particularly statistical process control. Chung Woon (2000) investigated the TQM implementation differences between manufacturing and service companies in 240 organizations in Singapore. The findings of this study indicated that the service organizations used the lower level of TQM practices especially quality performance and process management practices with compare to manufacturing organizations. In addition; there was no significant difference in some TQM practices such as customer focus, human resources and leadership. Prajogo (2005) investigated the difference of TQM implementation between 194 service industry and manufacturing industry in Australia. The findings of this paper have demonstrated that, there was not the significant difference between service firms and manufacturing firms in the level of TQM practices in two sectors. Fotopoulos and Psomas (2009) examined the linkage between hard elements and soft elements in 370 manufacturing and service companies in Greece. The results of this study found that, quality improvement and 
company market position were influenced on soft and hard TQM elements. Lenka, Suar and Mohapatra (2010) critically reviewed the literature of QM practices differences in both service and manufacturing industries. The findings of this study provided the comparison of service and manufacturing in Table 1.

Table 1. Comparison of TQM practices in service and manufacturing industry (source: adopted from Lenka et al., 2010)

\begin{tabular}{|l|l|}
\hline \multicolumn{1}{|c|}{ TQM practices in manufacturing industry } & \multicolumn{1}{|c|}{ TQM practices in service industry } \\
\hline Human and people oriented & Technology and tools oriented \\
\hline $\begin{array}{l}\text { Emphasize on top management commitment } \\
\text { and leadership }\end{array}$ & $\begin{array}{l}\text { Emphasize on top management commitment and } \\
\text { leadership }\end{array}$ \\
\hline Emphasize on continuous improvement & Emphasize on continuous improvement \\
\hline $\begin{array}{l}\text { Focus on communication skills and interna- } \\
\text { tional relationship }\end{array}$ & $\begin{array}{l}\text { Focus on technical skills regarding to selection re- } \\
\text { cruitment }\end{array}$ \\
\hline $\begin{array}{l}\text { Statistical process control is suitable in pro- } \\
\text { fessional services }\end{array}$ & Statistical process control is suggested universally \\
\hline Checks customer defections & Removal of product defects \\
\hline $\begin{array}{l}\text { Quality measurement by customer satisfac- } \\
\text { tion }\end{array}$ & Quality measurement through statistical tools \\
\hline
\end{tabular}

The majority of current studies in hotel and hospitality industry have investigated the role of TQM by presenting the various CSFs (Table 1), but there is a lack in current body of knowledge which did not provide the comprehensive list of TQM CSFs in hospitality industry. For this purpose, this study provided the comprehensive list of TQM CFSs based on hospitality literature and experts opinions. Moreover; although previous scholars in relationship on TQM and hospitality industry have examined different sets of TQM CSFs in their studies, but there is also lack of these studies which did not category those CSFs in the hard and soft aspects and one should also consider the situations and needs of hospitality industry when developing CSFs for them. In addition, most researchers focused on CSFs for implementation of TQM programs in developed countries, with but a few in developing countries (Calvo-Mora, Picón-Berjoyo, Ruiz-Moreno, \& Cauzo-Bottala, 2015; Nicholas, 2016). Although TQM is widely used in different industries in Iran (Gholamhossein, Jamal, Hamid Reza, \& Sajjad, 2016; Sadeh \& Garkaz, 2015), there is little evidence that it can improve the overall quality of specific industries such as hospitality (Mardani, Jusoh, Zavadskas, Zakuan, Valipour, \& Kazemilari, 2016; Mardani, Jusoh, Zavadskas, Khalifah, \& Nor, 2015), as each industry has different features. The current study presents a review of the literature on TQM and attempted to identify, evaluate and prioritizing various CSFs for implementation of TQM in the hospitality industry of developing countries such as Iran. Wu (2012), demonstrated the significance role of CSFs is a kind of qualitative decision-making problem and it is unavoidably included the imprecision of human decisions. As considered by Nonaka (1994), a mathematical approaches can handle vagueness in the process of decision-making is the fuzzy set theory. Therefore the purpose on this study to use the qualitative and quantitative methods by using Fuzzy Analytic Hierarchy Process (FAHP) and Fuzzy Delphi Method 
(FDM). Moreover, this paper reviewed and compared the TQM CSFs by numerous researchers in the field of hospitality literature.

\section{TQM critical success factors in hospitality industry}

A number of previous studies have investigated the importance role of TQM CSFs in hotel and hospitality industry. The summary of these studies is presented in Table 2. These CFSs been recognized as the important CSFs for implementation of TQM in the service industry such as hospitality and hotel (Camisón, 1996; Claver-Cortés, Pereira-Moliner, Tarí, \& Molina-Azorín, 2008; Pereira-Moliner, Claver-Cortés, Molina-Azorín, \& José Tarí, 2012; Wang, K. Y. Chen, \& S. C. Chen, 2012).

Table 2. List of CSFs presented by literature in hospitality industry (source: authors' elaboration)

\begin{tabular}{|c|c|c|}
\hline Aspects & CSFs & Studies \\
\hline \multirow{9}{*}{$\begin{array}{l}\text { Soft } \\
\text { CSFs }\end{array}$} & Leadership & $\begin{array}{l}\text { (Munanura, Tumwesigye, Sabuhoro, Mariza, \& Rugerinyange, 2017); (Pso- } \\
\text { mas \& Jaca, 2016); (Sadikoglu \& Olcay, 2014); (Akgün, Ince, Imamoglu, } \\
\text { Keskin, \& Kocoglu, 2014); (Aquilani et al., 2017); (Benavides-Velasco, } \\
\text { Quintana-García, \& Marchante-Lara, 2014); (Honarpour, Jusoh, \& Long, } \\
\text { 2017); (Jaca \& Psomas, 2015); (Mehralian, Nazari, Nooriparto, \& Rasekh, } \\
\text { 2017); (Nguyen \& Chau, 2017); (Patyal \& Koilakuntla, 2017); (Uluskan, } \\
\text { Godfrey, \& Joines, 2017); (Zwain, Lim, \& Othman, 2017) }\end{array}$ \\
\hline & $\begin{array}{l}\text { Process } \\
\text { management }\end{array}$ & $\begin{array}{l}\text { (Sadikoglu \& Olcay, 2014); (Akgün et al., 2014); (Aquilani et al., 2017); } \\
\text { (Cho, Jung, \& Linderman, 2017); (Nguyen \& Chau, 2017); (Patyal \& } \\
\text { Koilakuntla, 2017); (Uluskan et al., 2017); (Zeng, Zhang, Matsui, \& Zhao, } \\
\text { 2017) }\end{array}$ \\
\hline & $\begin{array}{l}\text { Customer } \\
\text { focus }\end{array}$ & $\begin{array}{l}\text { (Psomas \& Jaca, 2016); (Aquilani et al., 2017); (Benavides-Velasco et al., } \\
\text { 2014); (Cho et al., 2017); (Honarpour et al., 2017); (Jaca \& Psomas, 2015); } \\
\text { (Mehralian et al., 2017); (Nguyen \& Chau, 2017); (Zwain et al., 2017) }\end{array}$ \\
\hline & $\begin{array}{l}\text { Continuous } \\
\text { improve- } \\
\text { ment }\end{array}$ & $\begin{array}{l}\text { (Wang et al., 2012); (Pereira-Moliner et al., 2012); (Alvarez, Jaca, Viles, \& } \\
\text { Colomer, 2012); (Abd \& Al Manhawy, 2013); (Vähätiitto, 2010); (Talib, } \\
\text { Rahman, \& Qureshi, 2013); (Abu-Doleh, 2012); (Albacete-Sáez, Fuentes- } \\
\text { Fuentes, \& Bojica, 2011); (Honarpour et al., 2017); (Zwain et al., 2017) }\end{array}$ \\
\hline & $\begin{array}{l}\text { Employee } \\
\text { involvement }\end{array}$ & $\begin{array}{l}\text { (Talib et al., 2013); (Albacete-Sáez et al., 2011); (Holschbach \& Hofmann, } \\
\text { 2011); (Mehralian et al., 2017); (Prajogo \& Cooper, 2017); } \\
\text { (Zwain et al., 2017) }\end{array}$ \\
\hline & Teamwork & $\begin{array}{l}\text { (Alvarez et al., 2012); (Abd \& Al Manhawy, 2013); (Vähätiitto, 2010); } \\
\text { (Talib et al., 2013); (Abu-Doleh, 2012); (Aquilani et al., 2017); } \\
\text { (Cho et al., 2017); (Prajogo \& Cooper, 2017) }\end{array}$ \\
\hline & $\begin{array}{l}\text { Organiza- } \\
\text { tional com- } \\
\text { munication }\end{array}$ & $\begin{array}{l}\text { (Breiter \& Kline, 1995); (Mohsen, 2010); (Abd \& Al Manhawy, 2013); } \\
\text { (Vähätiitto, 2010); (Allison \& Byron, 1996); (Pearce \& Benckendorff, } \\
\text { 2006); (Talib et al., 2013); (Abu-Doleh, 2012); (Yapa, 2012) }\end{array}$ \\
\hline & $\begin{array}{l}\text { Education } \\
\text { and training }\end{array}$ & $\begin{array}{l}\text { (Munanura et al., 2017); (Sadikoglu \& Olcay, 2014); (Aquilani et al., 2017); } \\
\text { (Jaca \& Psomas, 2015); (Mehralian et al., 2017); (Munanura et al., 2017); } \\
\text { (Prajogo \& Cooper, 2017); (Zwain et al., 2017) }\end{array}$ \\
\hline & $\begin{array}{l}\text { Organiza- } \\
\text { tional } \\
\text { culture }\end{array}$ & $\begin{array}{l}\text { (Gupta, McDaniel, \& Herath, 2005); (Breiter \& Bloomquist, 1998); } \\
\text { (Vähätiitto, 2010); (Gotzamani, Longinidis, \& Vouzas, 2010) }\end{array}$ \\
\hline
\end{tabular}


End of Table 2

\begin{tabular}{|c|c|c|}
\hline Aspects & CSFs & Studies \\
\hline & $\begin{array}{l}\text { Internal/ex- } \\
\text { ternal coop- } \\
\text { eration }\end{array}$ & (Wang et al., 2012); (Albacete-Sáez et al., 2011) \\
\hline & $\begin{array}{l}\text { Employee } \\
\text { fulfillment }\end{array}$ & (Wang et al., 2012); (Abu-Doleh, 2012) \\
\hline & Learning & (Wang et al., 2012); (Albacete-Sáez et al., 2011) \\
\hline & $\begin{array}{l}\text { Organiza- } \\
\text { tional trust }\end{array}$ & (Y. K. Lee, Kim, K. H. Lee, \& Li, 2012) \\
\hline \multirow{12}{*}{$\begin{array}{l}\text { Hard } \\
\text { CSFs }\end{array}$} & $\begin{array}{l}\text { Quality } \\
\text { systems }\end{array}$ & $\begin{array}{l}\text { (Pereira-Moliner et al., 2012); (Abd \& Al Manhawy, 2013); (Pearce \& } \\
\text { Benckendorff, 2006) }\end{array}$ \\
\hline & $\begin{array}{l}\text { Quality im- } \\
\text { provement }\end{array}$ & (Abd \& Al Manhawy, 2013); (Kasongo \& Moono, 2010); (Yapa, 2012) \\
\hline & $\begin{array}{l}\text { Quality } \\
\text { assurance }\end{array}$ & (Mohsen, 2010); (Sila \& Ebrahimpour, 2003) \\
\hline & $\begin{array}{l}\text { ISO } 9000 \\
\text { series }\end{array}$ & (Alvarez et al., 2012); (Breiter \& Kline, 1995); (Yapa, 2012) \\
\hline & $\begin{array}{l}\text { Quality in- } \\
\text { formation }\end{array}$ & (Holschbach \& Hofmann, 2011); (Zu, Zhou, Zhu, \& Yao, 2011) \\
\hline & $\begin{array}{l}\text { Housekeep- } \\
\text { ing }\end{array}$ & $\begin{array}{l}\text { (Breiter \& Kline, 1995); (Moghadam, Sayadi, \& Moharer, 2013); (Zeng } \\
\text { et al., 2017) }\end{array}$ \\
\hline & $\begin{array}{l}\text { Benchmark- } \\
\text { ing }\end{array}$ & $\begin{array}{l}\text { (Talib et al., 2013); (Abu-Doleh, 2012); (Gotzamani et al., 2010); (Yapa, } \\
\text { 2012); (Ogden, 1998); (Cho et al., 2017); (Mehralian et al., 2017); (Mu- } \\
\text { nanura et al., 2017) }\end{array}$ \\
\hline & $\begin{array}{l}\text { Product/ser- } \\
\text { vice design }\end{array}$ & $\begin{array}{l}\text { (Talib et al., 2013); (Holschbach \& Hofmann, 2011); (Zu et al., 2011); } \\
\text { (Ahire \& Dreyfus, 2000); (Aquilani et al., 2017); (Mehralian et al., 2017); } \\
\text { (Patyal \& Koilakuntla, 2017) }\end{array}$ \\
\hline & $\begin{array}{l}\text { Planning for } \\
\text { quality }\end{array}$ & $\begin{array}{l}\text { (Pereira-Moliner et al., 2012); Claver-Cortés et al. (2008); (Mohsen, 2010); } \\
\text { (Abd \& Al Manhawy, 2013); (Oke, Ofiabulu, Banjo, \& Akanbi, 2008); } \\
\text { (Gotzamani et al., 2010) }\end{array}$ \\
\hline & $\begin{array}{l}\text { Design } \\
\text { Process } \\
\text { management }\end{array}$ & (Yang, 2006); (Sila \& Ebrahimpour, 2003); (Ahire \& Dreyfus, 2000) \\
\hline & $\begin{array}{l}\text { Pareto } \\
\text { Analysis }\end{array}$ & (Kasongo \& Moono, 2010); (Yapa, 2012) \\
\hline & $\begin{array}{l}\text { Quality } \\
\text { control }\end{array}$ & (Breiter \& Kline, 1995); (Mohsen, 2010); (Kasongo \& Moono, 2010) \\
\hline
\end{tabular}

\section{Methodology}

In the present study for evaluating of the important hard and soft CSFs TQM in hospitality industry, we have used expert's opinions, thus for calculation weight of each CFS, we applied FDM method. After this stage, we have been employed FAHP for calculating the criteria weight. According to the TQM literature and previous studies, 26 important factors have been proposed for evaluation of TQM evaluation in this study (Table 2). Fourteen experts 
participated in this study in order to evaluate 26 TQM CSFs in industry. This study selected the experts from both industrial and academic sectors. Fourteen Quality Management (QM) experts were invited from hospitality industry who have at least 10 years of working experience as a quality manager and TQM manager. The research methodology for this paper is schematically presented in Figure 1.

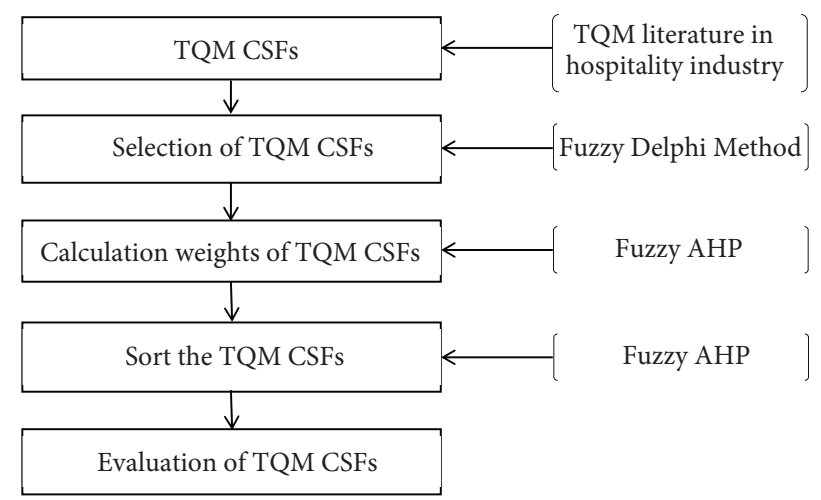

Figure 1. Research methodology follow chart (source: authors' elaboration)

\section{Results}

\subsection{Stage one: CSFs collection}

According to review of current literature, in total, 26 CSFs have been selected (Table 1). As an outcome, six more CSFs were suggested by the experts which presented in Table 3.

\subsection{Stage two: the FDM calculation}

At this stage, the questionnaires were given to the researchers in order to examine the TQM CSFs in hospitality industry. FDM process is presented as following stages:

1. For every linguistic variable, expert gives the corresponding interview.

2. Marked linguistic variables by the experts under each factor are converted to the corresponding interval.

3. For setting up a triangular fuzzy cognition that is most optimistic in every factor of and triangular fuzzy numbers cognition which is more conservative to where and are the minimum value, min geometry and the maximum value of the upper bound interval value factor and are the minimum value, min geometry and the maximum value of the lower bound interval value factor as characterized by an expert (Figure 2).

4. As shown in Figure 2, and the gray interval are greater than, it means the experts have reached a consensus on the perceived factors, or they have not reached a consensus and another round of the questionnaire needs to be conducted. If a consensus has been reached, the intermediate values within the gray interval shall be used to represent the expert group's evaluation values of the factors. 
5. Appropriate threshold is determined. If factor is larger than the threshold value, it is maintained or deleted otherwise.

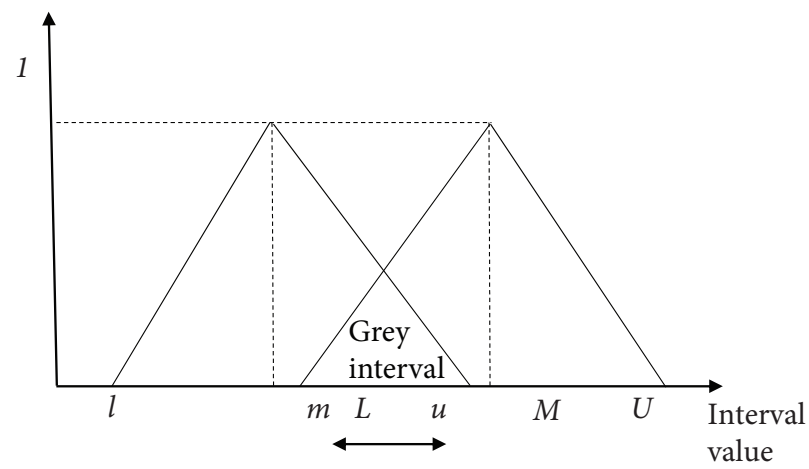

Figure 2. The FDM gray interval

Table 3. The FDM calculation (source: author's calculations)

\begin{tabular}{|l|c|c|c|c|c|c|}
\hline \multicolumn{1}{|c|}{ TQM CSFs } & Symbols & $t=(l, m, u)$ & $G$ & $T=(L, M, U)$ & $\frac{1}{2} G$ & $>\alpha$ \\
\hline Leadership & S1 & $(71,80.40,91)$ & $(91,78)$ & $(78,91.12,98)$ & 84.5 & $\checkmark$ \\
\hline Customer focus & S2 & $(74,84.42,91)$ & $(91,81)$ & $(81,93.13,100)$ & 86 & $\checkmark$ \\
\hline Employee involvement & S3 & $(69,74.48,80)$ & $(80,75)$ & $(75,82.48,87)$ & 77.5 & \\
\hline $\begin{array}{l}\text { Internal/external } \\
\text { cooperation }\end{array}$ & S4 & $(72,81.85,95)$ & $(95,82)$ & $(82,92.35,100)$ & 88.5 & $\checkmark$ \\
\hline Employee fulfillment & S5 & $(72,80.98,87)$ & $(87,82)$ & $(82,88.37,95)$ & 84.5 & $\checkmark$ \\
\hline Learning & S6 & $(66,74.73,82)$ & $(82,81)$ & $(81,84.66,89)$ & 81.5 & $\checkmark$ \\
\hline Process management & S7 & $(72,76.51,84)$ & $(84,79)$ & $(79,82.11,92)$ & 81.5 & $\checkmark$ \\
\hline $\begin{array}{l}\text { Cooperative supplier } \\
\text { relations }\end{array}$ & S8 & $(77,80.50,87)$ & $(87,82)$ & $(82,83.91,92)$ & 84.5 & $\checkmark$ \\
\hline Education and training & S9 & $(52,70.04,77)$ & $(77,69)$ & $(69,79.4,92)$ & 73 & \\
\hline Organizational culture & S10 & $(71,81.70,91)$ & $(91,81)$ & $(81,92.24,100)$ & 86 & $\checkmark$ \\
\hline Supplier management & S11 & $(63,69.13,75)$ & $(75,73)$ & $(73,79.13,83)$ & 74 & \\
\hline Organizational trust & S12 & $(71,80.05,86)$ & $(86,81)$ & $(81,86.94,94)$ & 83.5 & $\checkmark$ \\
\hline Teamwork & S13 & $(57,70.04,75)$ & $(75,72)$ & $(73,80.34,87)$ & 73.5 & \\
\hline $\begin{array}{l}\text { Organizational } \\
\text { communication }\end{array}$ & S14 & $(53,67.41,73)$ & $(73,68)$ & $(68,76.30,83)$ & 70.5 & \\
\hline Continuous improvement & S15 & $(57,69.34,79)$ & $(79,77)$ & $(77,80.25,92)$ & 78 & \\
\hline Quality control & H1 & $(72,78.71,85)$ & $(85,82)$ & $(82,87.95,95)$ & 83.5 & $\checkmark$ \\
\hline
\end{tabular}


End of Table 3

\begin{tabular}{|l|c|c|c|c|c|c|}
\hline \multicolumn{1}{|c|}{ TQM CSFs } & Symbols & $t=(l, m, u)$ & $G$ & $T=(L, M, U)$ & $\frac{1}{2} G$ & $>\alpha$ \\
\hline Quality improvement & H2 & $(72,76.94,84)$ & $(84,79)$ & $(79,82.04,92)$ & 81.5 & $\checkmark$ \\
\hline Quality assurance & H3 & $(66,74.33,88)$ & $(88,78)$ & $(78,85.03,100)$ & 83 & $\checkmark$ \\
\hline $\begin{array}{l}\text { Statistical Process Control } \\
\text { (SPC) }\end{array}$ & H4 & $(50,68.95,83)$ & $(83,70)$ & $(70,79.32,93)$ & 76.5 & \\
\hline ISO 9000 series & H5 & $(72,77.69,85)$ & $(85,82)$ & $(82,84.3,92)$ & 83.5 & $\checkmark$ \\
\hline Pareto Analysis & H6 & $(75,81.8,85)$ & $(87,85)$ & $(85,91.6,97)$ & 86 & $\checkmark$ \\
\hline Benchmarking & H7 & $(75,81.56,85)$ & $(85,82)$ & $(82,90.32,97)$ & 83.5 & $\checkmark$ \\
\hline Just-in-time (JIT) & H8 & $(75,78.6,83)$ & $(83,80)$ & $(80,85.63,93)$ & 81.5 & $\checkmark$ \\
\hline Housekeeping & H9 & $(51,68.32,80)$ & $(80,70)$ & $(70,78.32,91)$ & 75 & \\
\hline Process control & H10 & $(67,72.6,76)$ & $(76,74)$ & $(74,85.3,89)$ & 75 & \\
\hline Information feedback & H11 & $(66,73.78,86)$ & $(86,74)$ & $(74,75.68,83)$ & 80 & $\checkmark$ \\
\hline $\begin{array}{l}\text { Quality data and } \\
\text { reporting }\end{array}$ & H12 & $(75,78.31,85)$ & $(85,82)$ & $(82,83.28,88)$ & 83.5 & $\checkmark$ \\
\hline $\begin{array}{l}\text { Design Process } \\
\text { management }\end{array}$ & H13 & $(72,81.54,85)$ & $(85,82)$ & $(82,89.32,95)$ & 83.5 & $\checkmark$ \\
\hline Quality systems & H14 & $(54,67.26,77)$ & $(77,66)$ & $(66,76.43,82)$ & 71.5 & \\
\hline Quality information & H15 & $(57,68.31,85)$ & $(85,67)$ & $(67,77.02,92)$ & 76 & \\
\hline Product/service design & H16 & $(72,82.76,90)$ & $(90,80)$ & $(80,92.43,100)$ & 85 & $\checkmark$ \\
\hline Planning for quality & H17 & $(70,72.6,75)$ & $(75,79)$ & $(79,83.45,90)$ & 77 & \\
\hline
\end{tabular}

According to the data gathered through questionnaire and FDM calculation, a total of 20 TQM CSFs passed threshold value $\alpha$, this was taken into account as the most significant TQM CSFs. The results obtained in this step are shown in Table 3.

\subsection{Stage three: Fuzzy AHP step}

In this stage of study, we used FAHP to examine the relative importance of each TQM CSFs. After selecting of 20 important TQM CSFs by FDM in the final phase, the CSFs were placed into hierarchies through FAHP in order to calculate the weights. The steps of FAHP method is provided as follows:

Step 1: Creation the pairwise comparative matrixes

Once the 9-level assessment scale completed (Saaty, 1999), a set of questionnaire was proposed to examine the feelings of experts via a pairwise contrast among each pair of concepts/indicators (Table 4). Subsequent, the consequences were distorted to fuzzy numbers and fuzzy pair qualified matrices were produced by incomes of the technique presented by (Huang, Baetz, Patry, \& Terluk, 1997). 
Table 4. The definition of fuzzy number

\begin{tabular}{|l|c|}
\hline \multicolumn{1}{|c|}{ Definition } & Fuzzy number \\
\hline Extremely important & $\tilde{9}=(7,9,9)$ \\
\hline Intermediate value between extremely and very strongly important & $\tilde{8}=(6,8,9)$ \\
\hline Very strongly important & $\tilde{7}=(5,7,9)$ \\
\hline Intermediate value between very strongly and strongly important & $\tilde{6}=(4,6,8)$ \\
\hline Strongly important & $\tilde{5}=(3,5,7)$ \\
\hline Intermediate value between strongly and moderately important & $\tilde{4}=(2,4,6)$ \\
\hline Moderately important & $\tilde{3}=(1,3,5)$ \\
\hline Intermediate value between moderately and equally important & $\tilde{2}=(1,2,4)$ \\
\hline Equally important & $\tilde{1}=(1,1,3)$ \\
\hline
\end{tabular}

\section{Step 2: Group integration}

The geometric average technique suggested by Buckley (1985) was conducted for incorporation and the calculation can be obtainable as below:

$$
\tilde{M}_{i j}=\left(\prod_{i=1, j=1}^{N} m\right)^{1 / N}, I=1, \ldots, n .
$$

Where $\tilde{M}_{i j}$ signifies the triangular fuzzy number that is formed through group integration, $\tilde{M}_{i j}{ }^{N}$ indicates the expert $N$ 's pair comparison of indicators $i$ 's and $j$ 's importances, and $N$ represents the number of experts.

\section{Step 3: Building the fuzzy judgment matrices}

According to the previous step, a number of group integrated triangular fuzzy numbers were obtained, which can be employed to create the fuzzy judgment matrix for obtaining the fuzzy weight. The fuzzy judgment matrix can be offered as below:

$$
\begin{gathered}
M=\left[\tilde{M}_{i j}\right] ; \\
\tilde{M}_{i j}=\left(l_{i j}, m_{i j}, u_{i j}\right), \tilde{M}_{i j}=\frac{\tilde{1}}{M} i j, \cdots \forall_{i, j}=1,2, \wedge, n .
\end{gathered}
$$

Where $l_{i j}$ signifies the inferior value in the triangular fuzzy association purpose of the experts' sentiments on the indicator $j$ in TQM feature $i, m_{i j}$ indicates the average value in triangular fuzzy membership purpose of the experts' thoughts on the indicator $j$ in TQM feature $i$ and $u_{i j}$ stands intended for the greater value in triangular fuzzy association purpose of the experts' sentiments on indicator $j$ in managerial capabilities feature $i$. 
Step 4: Calculating the fuzzy weight

This study is focused on the calculation of fuzzy weight adapted from the method introduced by Buckley (1985). The calculation method is presented as follow:

$$
\begin{gathered}
\tilde{Z}_{i}=\left(\tilde{a}_{i 1} \times \tilde{a}_{i 2} \times \ldots \tilde{a}_{i n}\right)^{\frac{1}{n}}, \quad \forall_{i} ; \\
\tilde{W}_{i}=\left(\tilde{Z}_{1} \times\left(\tilde{Z}_{1}+\tilde{Z}_{2}+\tilde{Z}_{n}\right)^{)},\right.
\end{gathered}
$$

where $\tilde{a}_{i 1}$ indicates the triangular fuzzy quantity in row $i$ and column $j$ in the fuzzy judgment matrix, $\tilde{Z}_{i}$ signifies the geometric regular of the triangular fuzzy number, and $\tilde{W}_{i}$ signifies the fuzzy weight of indicator $i$.

\section{Step 5: Defuzzification}

Defuzzification of a fuzzy number into a crisp number can be completed through means of numerous approaches such as or the center of gravity defuzzifier, the adapted center average defuzzifier and the center average defuzzifier, mean of maxima defuzzifier, the modified mean of maxima defuzzifier. One of the greatest commonly-used approaches is the center of area method (COA). Therefore, in this research, the adapted COA technique presented by Tzeng and Teng (1993) has been used to defuzzification and ranking of the fuzzy number. The following equation defuzzifier a triangular fuzzy number $\tilde{a}_{i 1}=\left(l_{i j}, m_{i j}, u_{i j}\right)$ into a crisp number.

$$
D F_{i 1}=\frac{\left[\left(u_{i j}-l_{i j}\right)+\left(m_{i j}-l_{i j}\right)\right]}{3}+l_{i j} .
$$

\begin{tabular}{|c|c|c|c|c|c|}
\hline Dimension & $\begin{array}{l}\text { Defuzzied } \\
\text { weight }\end{array}$ & CSFs & $\begin{array}{l}\text { Defuzzied } \\
\text { weight }\end{array}$ & $\begin{array}{l}\text { Weight } \\
\text { global }\end{array}$ & Ranking \\
\hline \multirow{9}{*}{ Soft aspect } & \multirow{9}{*}{0.6139} & S1 & 0.185 & 0.1136 & 3 \\
\hline & & S2 & 0.186 & 0.1142 & 2 \\
\hline & & S4 & 0.215 & 0.1320 & 1 \\
\hline & & S5 & 0.085 & 0.0522 & 7 \\
\hline & & S6 & 0.054 & 0.0331 & 12 \\
\hline & & S7 & 0.102 & 0.0627 & 5 \\
\hline & & S8 & 0.053 & 0.0325 & 14 \\
\hline & & S10 & 0.050 & 0.0307 & 15 \\
\hline & & $\mathrm{S} 12$ & 0.049 & 0.0301 & 16 \\
\hline \multirow{5}{*}{ Hard aspects } & \multirow{5}{*}{0.3861} & $\mathrm{H} 1$ & 0.062 & 0.0240 & 20 \\
\hline & & $\mathrm{H} 2$ & 0.065 & 0.0251 & 19 \\
\hline & & $\mathrm{H} 3$ & 0.096 & 0.0371 & 10 \\
\hline & & H5 & 0.085 & 0.0328 & 13 \\
\hline & & H6 & 0.093 & 0.0359 & 11 \\
\hline
\end{tabular}

Calculating the fuzzy weight and defuzzification of TQM CSFs showed in Table 5.

Table 5. TQM CSFs Defuzzied weight (source: authors' elaboration) 
End of Table 5

\begin{tabular}{|c|c|c|c|c|c|}
\hline Dimension & $\begin{array}{c}\text { Defuzzied } \\
\text { weight }\end{array}$ & CSFs & $\begin{array}{c}\text { Defuzzied } \\
\text { weight }\end{array}$ & $\begin{array}{c}\text { Weight } \\
\text { global }\end{array}$ & Ranking \\
\hline \multirow{4}{*}{} & \multirow{4}{*}{} & H7 & 0.195 & 0.0753 & 4 \\
\cline { 3 - 6 } & H8 & 0.070 & 0.0270 & 18 \\
\cline { 3 - 6 } & H11 & 0.139 & 0.0537 & 6 \\
\cline { 3 - 6 } & H12 & 0.103 & 0.0398 & 8 \\
\cline { 3 - 6 } & H13 & 0.090 & 0.0374 & 9 \\
\cline { 3 - 6 } & & H16 & 0.072 & 0.0278 & 17 \\
\hline
\end{tabular}

According to the results of FDM and FAHP, this study presented the important of hard and soft TQM CSFs in hospitality industry. The evaluation of the hierarchical structure of TQM CSFs classified based on two aspects (soft and hard) and 20 evaluated CSFs, as shown in Figure 3.

\section{Discussion}

The results of this study showed that the important CSFs in Iranian hospitality industry were related to soft aspects. Internal/external cooperation had the first with compare to other soft CSFs. Customer focus was the second rank (0.1142) of TQM CSFs in this study. This finding supports by some of previous studies such as; Alvarez et al. (2012), Talib and Rahman (2010), Claver, Tarí and Pereira (2006) and Wang et al. (2012). Wang et al. (2012) identified and ranked the nine importance CSFs such as; customer focus (second rank) for services industry and proposed a model for services organizations TQM implementation.

Wang et al. (2012), reported that the TQM elements such as the customer focus (factor loading, 0.75) are the most significant for the hotel TQM practices. To this end, managers should enhance their own and all employees' awareness of the changing needs regarding the customers and market demands. Molina-Azorín, Tarí, Pereira-Moliner, López-Gamero, and Pertusa-Ortega (2015) examined the relationship among environmental management, QM practices and competitive advantage in hotels, the results of this paper indicated that, strategic practices such as customer focus is the key quality practices to predict the competitive advantage in hotels. Pereira-Moliner, Pertusa-Ortega, Tarí, López-Gamero and Molina-Azorín (2016) investigated the relationships among QM, organizational design and competitive advantage in hotels, this study argued that the development of QM practices promotes satisfaction of customers of hotels. Del Alonso-Almeida, Bagur-Femenías and Llach (2015) indicated the customer satisfaction directly and positively influenced on competitiveness of company.

In addition, according to the factors' weights, the third CSF of soft TQM was leadership (0.1136). According to WenJung (2013), leadership exerts the greatest effect on the internal service quality, and hotel managers create a clear perception of the vision and mission through communications and authorized means for encouraging employees to develop their beneficial behaviors and innovative ideas toward the internal service. Del Alonso-Almeida et al. (2015) indicated the QM practices such as management commitment influenced on operation performance, customer satisfaction and employee work directly and positively. 


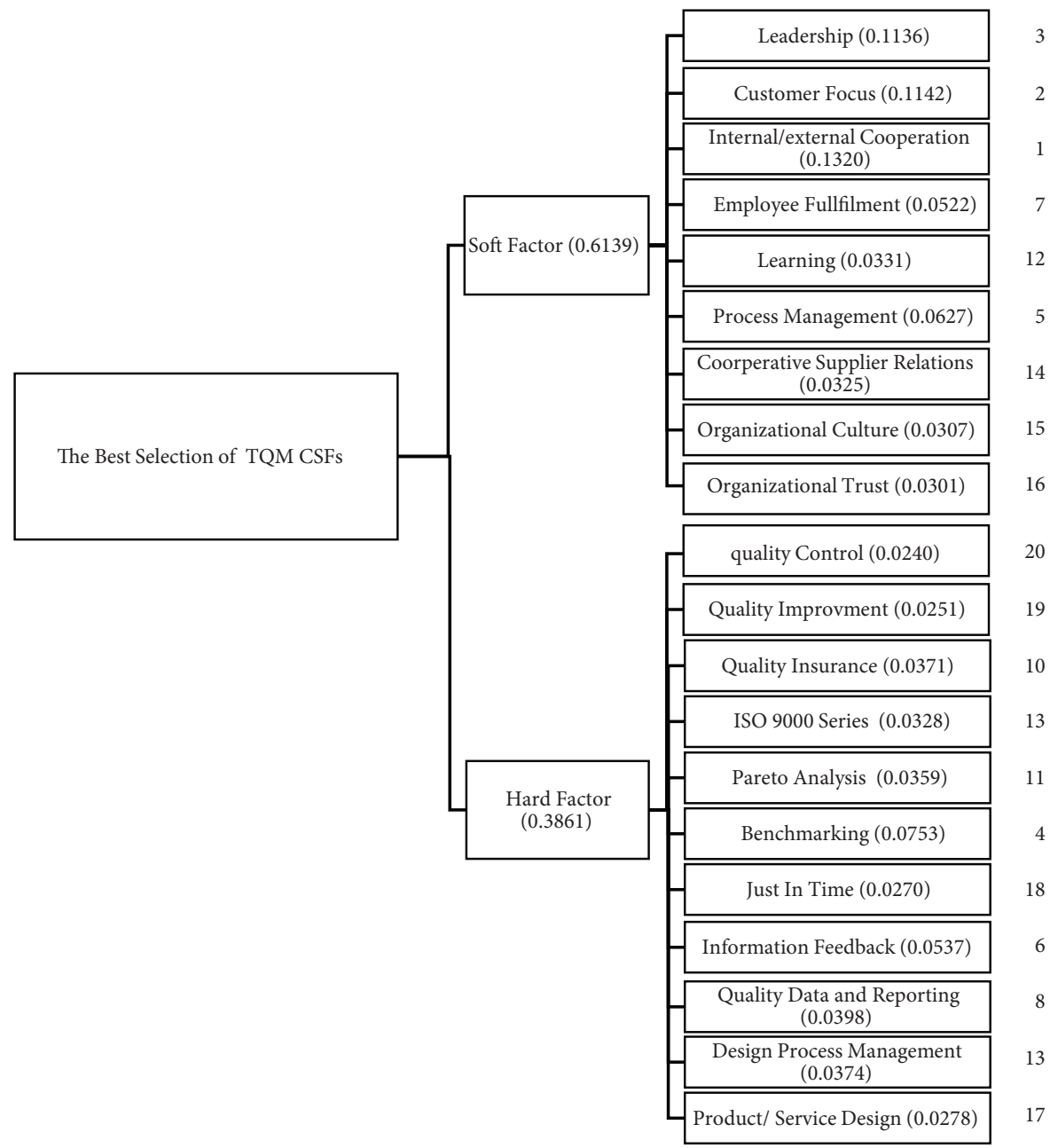

Figure 3. The hierarchy structure evaluation for TQM CSFs

Benavides-Velasco et al. (2014) demonstrated that, QM enablers such as leadership had the positive relationship with customers and employees.

In the aspect of hard TQM CSFs, the significant factor was benchmarking (0.0753). This finding is supported by previous study. For example; Dow, Samson and Ford (1999), found that the use of the SPC measures, flexible manufacturing systems, and benchmarking improve the firms performance. Nair and Choudhary (2016) indicated that, there is need to consider the role of some QM initiatives such as benchmarking by top management for improve and reap the benefits in field of hospitality industry.

\section{Conclusions}

In this study, an approach is proposed to combine focus group, FAHP, and FDM in order to develop the hierarchical framework to evaluate hard and soft TQM CSFs in the hospitality 
industry. Serious competition among hotels precipitates the requirement for the QM issues. The findings of this study demonstrated that, internal/external cooperation, customer focus and leadership were the important soft TQM CSFs in field of hospitality.

In the future, several other techniques such fuzzy preference relations and entropy can be used by the researchers for calculation weights of TQM CSFs. Furthermore, the practitioners and managers can use the proposed approach to evaluate the company's quality level and compare the findings of this study with other methods. Moreover, the understanding of the basic TQM practices highlighted in this research study help the managers to improve their knowledge and enhance the potential of the traditional quality system.

The present study has the following contributions: the first contribution of present study is identifying and presenting the comprehensive list of TQM CSFs based on literature review on hospitality industry. Second; category of TQM CSFs based on hard and soft aspects for hospitality industry, third; the first study that using the Fuzzy Delphi Method for identifying the important of TQM CSFs in hospitality industry, fourth; we integrated FDM and FAHP approaches to identify, evaluate and rank the importance of TQM CSFs in hospitality industry.

\section{Acknowledgements}

The author (s) disclosed receipt of the following financial support for the research, authorship, and/or publication of this article: The authors would like to thank the Research Management Center (RMC) at Universiti Teknologi Malaysia (UTM) and Ministry of Higher Education (Malaysia) for supporting and funding this research under the Fundamental Research Grant Scheme (FRGS) (Vote no. FRGS/1/2016/WAB12/UTM/01/2).

\section{Author contributions}

All authors contributed equally to this work.

\section{Funding}

This work was supported by the < Research Management Centre (RMC) at Universiti Teknologi Malaysia (UTM) and Ministry of Higher Education (Malaysia)> under Fundamental Research Grant Scheme (FRGS) [FRGS/1/2016/WAB12/UTM/01/2].

\section{References}

Abd, W. Y. M. P. D., \& Al Manhawy, A. (2013). TQM critical success factors in hospitality Industry and their impact on Customer Loyalty, a theoretical Model. International Journal of Scientific and Engineering Research, 4(1), 1-15.

Abu-Doleh, J. D. (2012). Human resource management and total quality management linkage-rhetoric and reality: evidence from an empirical study. International Journal of Commerce and Management, 22(3), 219-234. https://doi.org/10.1108/10569211211260300 
Ahire, S. L., \& Dreyfus, P. (2000). The impact of design management and process management on quality: an empirical investigation. Journal of Operations Management, 18(5), 549-575.

https://doi.org/10.1016/S0272-6963(00)00029-2

Akgün, A. E., Ince, H., Imamoglu, S. Z., Keskin, H., \& Kocoglu, İ. (2014). The mediator role of learning capability and business innovativeness between total quality management and financial performance. International Journal of Production Research, 52(3), 888-901. https://doi.org/10.1080/00207543.2013.843796

Albacete-Sáez, C. A., Fuentes-Fuentes, M. M., \& Bojica, A. M. (2011). Quality management, strategic priorities and performance: the role of quality leadership. Industrial Management and Data Systems, 111(8), 1173-1193. https://doi.org/10.1108/02635571111170758

Allison, J. H., \& Byron, M. A. (1996). Aligning quality improvement with strategic goals at ANA Hotel San Francisco. National Productivity Review, 15(2), 89-99. https://doi.org/10.1002/npr.4040150210

Alvarez, M. J., Jaca, C., Viles, E., \& Colomer, A. (2012). Quality management in hotels in the Basque Country. International Journal of Quality and Service Sciences, 4(1), 51-60. https://doi.org/10.1108/17566691211219724

Andrade, J., Mendes, L., \& Lourenço, L. (2017). Perceived psychological empowerment and total quality management-based quality management systems: an exploratory research. Total Quality Management \& Business Excellence, 28(1-2), 76-87. https://doi.org/10.1080/14783363.2015.1050166

Aoun, M., \& Hasnan, N. (2017). Health-care technology management: developing the innovation skills through implementing soft TQM among Lebanese hospitals. Total Quality Management \& Business Excellence, 28(1-2), 1-11. https://doi.org/10.1080/14783363.2015.1043881

Aquilani, B., Aquilani, B., Silvestri, C., Silvestri, C., Ruggieri, A., Ruggieri, A., Gatti, C., \& Gatti, C. (2017). A systematic literature review on total quality management critical success factors and the identification of new avenues of research. The TQM Journal, 29(1), 184-213. https://doi.org/10.1108/TQM-01-2016-0003

Beaumont, N. B., Sohal, A. S., \& Terziovski, M. (1997). Comparing quality management practices in the Australian service and manufacturing industries. International Journal of Quality and Reliability Management, 14(8), 814-833. https://doi.org/10.1108/02656719710181321

Benavides-Velasco, C. A., Quintana-García, C., \& Marchante-Lara, M. (2014). Total quality management, corporate social responsibility and performance in the hotel industry. International Journal of Hospitality Management, 41, 77-87. https://doi.org/10.1016/j.ijhm.2014.05.003

Bouranta, N., N., Psomas, E. L., \& Pantouvakis, A. (2017). Identifying the critical determinants of TQM and their impact on company performance: evidence from the hotel industry of Greece. The TQM Journal, 29(1), 147-166. https://doi.org/10.1108/TQM-11-2015-0142

Breiter, D., \& Bloomquist, P. (1998). TQM in American hotels: an analysis of appllication. The Cornell Hotel and Restaurant Administration Quarterly, 39(1), 26-33. https://doi.org/10.1016/S0010-8804(97)83879-7

Breiter, D., \& Kline, S. F. (1995). Benchmarking quality management in hotels. Hospitality Review, 13(2), 6.

Buckley, J. J. (1985). Fuzzy hierarchical analysis. Fuzzy Sets and Systems, 17(2), 233-247. https://doi.org/10.1016/0165-0114(85)90090-9

Calvo-Mora, A., Picón-Berjoyo, A., Ruiz-Moreno, C., \& Cauzo-Bottala, L. (2015). Contextual and mediation analysis between TQM critical factors and organisational results in the EFQM Excellence Model framework. International Journal of Production Research, 53(7), 2186-2201. https://doi.org/10.1080/00207543.2014.975859

Camisón, C. (1996). Total quality management in hospitality: an application of the EFQM model. Tourism Management, 17(3), 191-201. https://doi.org/10.1016/0261-5177(96)00006-4 
Cho, Y. S., Jung, J. Y., \& Linderman, K. (2017). The QM evolution: behavioral quality management as a firm's strategic resource. International Journal of Production Economics, 191, 233-249. https://doi.org/10.1016/j.ijpe.2017.05.002

Chuang, S. S., Chen, K. S., \& Tsai, M. T. (2015). Exploring the antecedents that influence middle management employees' knowledge-sharing intentions in the context of total quality management implementations. Total Quality Management and Business Excellence, 26(1-2), 108-122. https://doi.org/10.1080/14783363.2013.809941

Chung Woon, K. (2000). TQM implementation: comparing Singapore's service and manufacturing leaders. Managing Service Quality: an International Journal, 10(1-2), 318-331. https://doi.org/10.1108/09604520010345777

Claver-Cortés, E., Pereira-Moliner, J., Tarí, J. J., \& Molina-Azorín, J. F. (2008). TQM, managerial factors and performance in the Spanish hotel industry. Industrial Management and Data Systems, 108(2), 228-244. https://doi.org/10.1108/02635570810847590

Claver, E., Tarí, J. J., \& Pereira, J. (2006). Does quality impact on hotel performance? International Journal of Contemporary Hospitality Management, 18(4), 350-358. https://doi.org/10.1108/09596110610665357

del Alonso-Almeida, M. M., Bagur-Femenías, L., \& Llach, J. (2015). The adoption of quality management practices and their impact on business performance in small service companies: the case of Spanish travel agencies. Service Business, 9(1), 57-75. https://doi.org/10.1007/s11628-013-0218-6

Dow, D., Samson, D., \& Ford, S. (1999). Exploding the myth: do all quality management practices contribute to superior quality performance? Production and Operations Management, 8(1), 1-27. https://doi.org/10.1111/j.1937-5956.1999.tb00058.x

Drosos, D., Skordoulis, M., Chalikias, M., Kalantonis, P., \& Papagrigoriou, A. (2017). The impact of ISO 9001 quality management system implementation in tourism SMEs. In V. Katsoni, A. Upadhya, \& A. Stratigea (Eds.), Tourism, Culture and Heritage in a Smart Economy (pp. 145-157). Springer. https://doi.org/10.1007/978-3-319-47732-9_10

Fernandes, A. C., Sampaio, P., Sameiro, M., \& Truong, H. Q. (2017). Supply chain management and quality management integration: a conceptual model proposal. International Journal of Quality \& Reliability Management, 34(1), 53-67. https://doi.org/10.1108/IJQRM-03-2015-0041

Fotopoulos, C. B., \& Psomas, E. L. (2009). The impact of "soft" and "hard" TQM elements on quality management results. International Journal of Quality \& Reliability Management, 26(2), 150-163. https://doi.org/10.1108/02656710910928798

Fu, S. L., Chou, S. Y., Chen, C. K., \& Wang, C. W. (2015). Assessment and cultivation of total quality management organisational culture - an empirical investigation. Total Quality Management and Business Excellence, 26(1-2), 123-139. https://doi.org/10.1080/14783363.2014.970760

Gholamhossein, M., Jamal, A. N., Hamid Reza, R., \& Sajjad, H. (2016). TOPSIS approach to prioritize critical success factors of TQM: evidence from the pharmaceutical industry. The TQM Journal, 28(2), 235-249. https://doi.org/10.1108/TQM-03-2014-0028

Gotzamani, K., Longinidis, P., \& Vouzas , F. (2010). The logistics services outsourcing dilemma: quality management and financial performance perspectives. Supply Chain Management: an International Journal, 15(6), 438-453. https://doi.org/10.1108/13598541011080428

Gupta, A., McDaniel, J. C., \& Herath, S. K. (2005). Quality management in service firms: sustaining structures of total quality service. Managing Service Quality, 15(4), 389-402. https://doi.org/10.1108/09604520510606853

Holschbach, E., \& Hofmann, E. (2011). Exploring quality management for business services from a buyer's perspective using multiple case study evidence. International Journal of Operations \& Production Management, 31(6), 648-685. https://doi.org/10.1108/01443571111131980 
Honarpour, A., Jusoh, A., \& Long, C. S. (2017). Knowledge management and total quality management: a reciprocal relationship. International Journal of Quality and Reliability Management, 34(1), 91-102. https://doi.org/10.1108/IJQRM-03-2014-0040

Huang, G., Baetz, B., Patry, G., \& Terluk, V. (1997). Capacity planning for an integrated waste management system under uncertainty: a North American case study. Waste Management and Research, 15(5), 523-546. https://doi.org/10.1177/0734242X9701500507

Jaca, C., \& Psomas, E. (2015). Total quality management practices and performance outcomes in Spanish service companies. Total Quality Management and Business Excellence, 26(9-10), 958-970. https://doi.org/10.1080/14783363.2015.1068588

Kasongo, C., \& Moono, M. (2010). Factors that lead to a successful TQM implementation: a case study on the Zambian Tourism Industry. Laurea University of Applied Sciences.

Lee, Y. K., Kim, Y., Lee, K. H., \& Li, D. X. (2012). The impact of CSR on relationship quality and relationship outcomes: a perspective of service employees. International Journal of Hospitality Management, 31(3), 745-756. https://doi.org/10.1016/j.ijhm.2011.09.011

Lenka, U., Suar, D., \& Mohapatra, P. K. (2010). Customer satisfaction in Indian commercial banks through total quality management approach. Total Quality Management and Business Excellence, 21(12), 1315-1341. https://doi.org/10.1080/14783363.2010.530773

Mardani, A., Jusoh, A., Zavadskas, E. K., Khalifah, Z., \& Nor, K. M. D. (2015). Application of multiplecriteria decision-making techniques and approaches to evaluating of service quality: a systematic review of the literature. Journal of Business Economics and Management, 16(5), 1034-1068. https://doi.org/10.3846/16111699.2015.1095233

Mardani, A., Jusoh, A., Zavadskas, E.K., Zakuan, N., Valipour, A., Kazemilari, M., 2016. Proposing a new hierarchical framework for the evaluation of quality management practices: a new combined fuzzy hybrid MCDM approach. Journal of Business Economics and Management, 17(1), 1-16.

Mehralian, G., Nazari, J. A., Nooriparto, G., \& Rasekh, H. R. (2017). TQM and organizational performance using the balanced scorecard approach. International Journal of Productivity and Performance Management, 66(1), 111-125. https://doi.org/10.1108/IJPPM-08-2015-0114

Moghadam, M. S., Sayadi, E., \& Moharer, A. (2013). Study strategy Total Quality Management in the hotel industry of sports in Iran. Global Advanced Journal of Economics, Accounting and Finance, 2(1), 1-8.

Mohsen, M. A. M. S. (2010). The introduction of a total quality management culture in hotels. University of Wales, Cardiff, Wales, UK.

Molina-Azorín, J. F., Tarí, J. J., Pereira-Moliner, J., López-Gamero, M. D., \& Pertusa-Ortega, E. M. (2015). The effects of quality and environmental management on competitive advantage: a mixed methods study in the hotel industry. Tourism Management, 50, 41-54.

https://doi.org/10.1016/j.tourman.2015.01.008

Munanura, I. E., Tumwesigye, B., Sabuhoro, E., Mariza, D., \& Rugerinyange, L. (2017). The quality and performance nexus of the community-based ecotourism enterprises at Nyungwe National Park, Rwanda: a total quality management perspective. Journal of Ecotourism, 1-24. https://doi.org/10.1080/14724049.2017.1304945

Nair, G. K., \& Choudhary, N. (2016). Influence of critical success factors of total quality management on financial and non-financial performance of hospitality industry: an empirical study. International Journal of Productivity and Quality Management, 17(4), 409-436. https://doi.org/10.1504/IJPQM.2016.075243

Nguyen, V. C., \& Chau, N. T. (2017). Research framework for the impact of total quality management on competitive advantage: the mediating role of innovation performance. Review of International Business and Strategy, 27(3), 335-351. https://doi.org/10.1108/RIBS-02-2017-0016 
Nicholas, J. (2016). Hoshin kanri and critical success factors in quality management and lean production. Total Quality Management and Business Excellence, 27(3-4), 250-264. https://doi.org/10.1080/14783363.2014.976938

Nonaka, I. (1994). A dynamic theory of organizational knowledge creation. Organization Science, 5(1), 14-37. https://doi.org/10.1016/B978-0-7506-7111-8.50003-2

Ogden, S. M. (1998). Comment: benchmarking and best practice in the small hotel sector. International Journal of Contemporary Hospitality Management, 10(5), 189-190. https://doi.org/10.1108/09596119810227794

Oke, S., Ofiabulu, C., Banjo, A., \& Akanbi, O. (2008). The combined application of quality function deployment and Pareto analysis for hotel services improvement. International Journal of Productivity and Quality Management, 3(2), 241-262. https://doi.org/10.1504/IJPQM.2008.016567

Patyal, V. S., \& Koilakuntla, M. (2017). The impact of quality management practices on performance: an empirical study. Benchmarking: an International Journal, 24(2), 511-535. https://doi.org/10.1108/BIJ-11-2015-0109

Pearce, P., \& Benckendorff, P. (2006). Benchmarking, usable knowledge and tourist attractions. Journal of Quality Assurance in Hospitality and Tourism, 7(1-2), 29-52. https://doi.org/10.1300/J162v07n01_03

Pereira-Moliner, J., Claver-Cortés, E., Molina-Azorín, J. F., \& José Tarí, J. (2012). Quality management, environmental management and firm performance: direct and mediating effects in the hotel industry. Journal of Cleaner Production, 37, 82-92. https://doi.org/10.1016/j.jclepro.2012.06.010

Pereira-Moliner, J., Pertusa-Ortega, E. M., Tarí, J. J., López-Gamero, M. D., \& Molina-Azorín, J. F. (2016). Organizational design, quality management and competitive advantage in hotels. International Journal of Contemporary Hospitality Management, 28(4), 762-784. https://doi.org/10.1108/IJCHM-10-2014-0545

Prajogo, D. I. (2005). The comparative analysis of TQM practices and quality performance between manufacturing and service firms. International Journal of Service Industry Management, 16(3), 217228. https://doi.org/10.1108/09564230510601378

Prajogo, D. I., \& Cooper, B. (2017). The individual and organizational level effects of TQM practices on job satisfaction. International Journal of Manpower, 38(2), 215-225. https://doi.org/10.1108/IJM-12-2014-0240

Psomas, E. L., \& Jaca, C. (2016). The impact of total quality management on service company performance: evidence from Spain. International Journal of Quality and Reliability Management, 33(3), 380-398. https://doi.org/10.1108/IJQRM-07-2014-0090

Saaty, T. L. (1999). Decision making for leaders: the analytic hierarchy process for decisions in a complex world. RWS publications, University of Pittsburgh, United State.

Sadeh, E., \& Garkaz, M. (2015). Explaining the mediating role of service quality between quality management enablers and students' satisfaction in higher education institutes: the perception of managers. Total Quality Management and Business Excellence, 26(11-12), 1335-1356. https://doi.org/10.1080/14783363.2014.931065

Sadikoglu, E., \& Olcay, H. (2014). The effects of total quality management practices on performance and the reasons of and the barriers to TQM practices in Turkey. Advances in Decision Sciences, 2014, (Article ID 537605). https://doi.org/10.1155/2014/537605

Sila, I., \& Ebrahimpour, M. (2003). Examination and comparison of the critical factors of total quality management (TQM) across countries. International Journal of Production Research, 41(2), 235-268. https://doi.org/10.1080/0020754021000022212

Talib, F., \& Rahman, Z. (2010). Critical success factors of TQM in service organizations: a proposed model. Services Marketing Quarterly, 31(3), 363-380. https://doi.org/10.1080/15332969.2010.486700 
Talib, F., Rahman, Z., \& Qureshi, M. (2013). An empirical investigation of relationship between total quality management practices and quality performance in Indian service companies. International Journal of Quality and Reliability Management, 30(3), 280-318. https://doi.org/10.1108/02656711311299845

Tarí, J. J., Pereira-Moliner, J., Pertusa-Ortega, E. M., López-Gamero, M. D., \& Molina-Azorín, J. F. (2017). Does quality management improve performance or vice versa? Evidence from the hotel industry. Service Business, 11(1), 23-43. https://doi.org/10.1007/s11628-015-0298-6

Tzeng, G. H., \& Teng, J. Y. (1993). Transportation investment project selection with fuzzy multiobjectives. Transportation Planning and Technology, 17(2), 91-112. https://doi.org/10.1080/03081069308717504

Uluskan, M., Godfrey, A. B., \& Joines, J. A. (2017). Integration of Six Sigma to traditional quality management theory: an empirical study on organisational performance. Total Quality Management and Business Excellence, 28(13-14), 1526-1543. https://doi.org/10.1080/14783363.2016.1150173

Vähätiitto, J. (2010). Environmental quality management in hospitality industry-Case Hotel K5 Levi (Master's thesis). Department of Business Technology Aalto University School of Economics.

Wang, C. H., Chen, K. Y., \& Chen, S. C. (2012). Total quality management, market orientation and hotel performance: the moderating effects of external environmental factors. International Journal of Hospitality Management, 31(1), 119-129. https://doi.org/10.1016/j.ijhm.2011.03.013

WenJung, C. (2013). Factors influencing internal service quality at international tourist hotels. International Journal of Hospitality Management, 35, 152-160. https://doi.org/10.1016/j.ijhm.2013.06.004

$\mathrm{Wu}, \mathrm{W}$. W. (2012). Segmenting critical factors for successful knowledge management implementation using the fuzzy DEMATEL method. Applied Soft Computing, 12(1), 527-535. https://doi.org/10.1016/j.asoc.2011.08.008

Yang, C. C. (2006). Establishment of a quality-management system for service industries. Total Quality Management and Business Excellence, 17(9), 1129-1154. https://doi.org/10.1080/14783360600750428

Yapa, S. (2012). Total quality management in Sri Lankan service organizations. The TQM Journal, 24(6), 505-517. https://doi.org/10.1108/17542731211270070

Zeng, J., Zhang, W., Matsui, Y., \& Zhao, X. (2017). The impact of organizational context on hard and soft quality management and innovation performance. International Journal of Production Economics, 185, 240-251. https://doi.org/10.1016/j.ijpe.2016.12.031

Zu, X., Zhou, H., Zhu, X., \& Yao, D. (2011). Quality management in China: the effects of firm characteristics and cultural profile. International Journal of Quality and Reliability Management, 28(8), 800-821. https://doi.org/10.1108/02656711111162497

Zwain, A. A. A., Lim, K. T., \& Othman, S. N. (2017). TQM and academic performance in Iraqi HEIs: associations and mediating effect of KM. The TQM Journal, 29(2), 357-368.

https://doi.org/10.1108/TQM-08-2013-0096 